\title{
Role of the Universities as Drivers of Social Innovation
}

\author{
Cristina Puente ${ }^{1, *} \mathbb{0}$, María Eugenia Fabra ${ }^{2}$, Cindy Mason $^{3}$, Cristina Puente-Rueda $^{1}(\mathbb{D}$, \\ Maria Ana Sáenz-Nuño ${ }^{4}$ and Ramiro Viñuales ${ }^{1}$ \\ 1 Computer Science Department, ICAI School of Engineering, Comillas Pontifical University, \\ 28015 Madrid, Spain; puenterueda.c@gmail.com (C.P.-R.); rvinuales@icai.comillas.edu (R.V.) \\ 2 Department of Quantitative Methods, ICADE, Comillas Pontifical University, 28015 Madrid, Spain; \\ mefabra@icade.comillas.edu \\ 3 BISC, EECS Department, University of California, Berkeley, Berkeley, CA 94709, USA; \\ cindymason@media.mit.edu \\ 4 Institute for Research in Technology (IIT), ICAI School of Engineering, Comillas Pontifical University, \\ 28015 Madrid, Spain; msaenz@iit.comillas.edu \\ * Correspondence: cristina.puente@comillas.edu
}

Citation: Puente, C.; Fabra, M.E.;

Mason, C.; Puente-Rueda, C.;

Sáenz-Nuño, M.A.; Viñuales, R. Role of the Universities as Drivers of Social Innovation. Sustainability 2021, 13, 13727. https://doi.org/10.3390/ su132413727

Academic Editors: Adela

García-Aracil and Rosa Isusi-Fagoaga

Received: 16 October 2021

Accepted: 20 November 2021

Published: 13 December 2021

Publisher's Note: MDPI stays neutral with regard to jurisdictional claims in published maps and institutional affiliations.

Copyright: (C) 2021 by the authors. Licensee MDPI, Basel, Switzerland. This article is an open access article distributed under the terms and conditions of the Creative Commons Attribution (CC BY) license (https:/ / creativecommons.org/licenses/by/ $4.0 /)$.

\begin{abstract}
The role of universities as drivers of good practices and learning has changed radically in recent years. The strategic plan of the Comillas Pontifical University establishes the obligation of a learning and service subject in all degree programs as a way to put what has been learned during the university years at the service of society and as a vehicle for promoting the Sustainable Development Goals set by the 2030 Agenda. In this article we will present the theoretical framework on which the project has been developed, including the university context in which it fits, to analyze the process of design and implementation of a service-learning course in engineering degrees, selecting as case studies two examples of projects in which the social impact was high. As conclusions we will present the strengths and weaknesses of the implementation process, as well as the students' learning based on their experiences.
\end{abstract}

Keywords: social innovation; learning and service; Sustainable Development Goals; social engineering; learning and service engineering projects; high education

\section{Introduction}

The European Commission in its 2030 agenda for sustainable development defines 17 goals (SDGs) to create the roadmap towards a better world and the global framework for international cooperation and sustainable development. With regards to SGD 1 (End poverty in all its forms everywhere), while significant challenges will remain, by 2030 the EU is expected to have made significant progress in poverty eradication and social inclusion by achieving access for all to adequate and quality social protection, (health, education, housing and social services).

This objective is highly complex since it requires profound structural changes capable of transforming existing social paradigms [1], as well as the creation of new social networks that evolve towards new structures [2] with collaborative approaches, with different organizational forms and with novel perspectives on the use of resources [3].

Within the framework of this transformational challenge, social innovation has emerged "[ ... ] as an attempt to capture and describe bottom-up phenomena where new ideas, approaches, techniques, and organizational forms grow from humble roots into substantive new social capacities." [4], as an approach to ensure new products, markets, processes and services to drive structural changes [5,6].

The role of social innovation as a driver of sustainable development and smart and inclusive growth [7] has made academic and research increasingly interested in this concept [8], approaching it from the discussion of conceptual aspects and its evolution [9-17] until the analysis of its transformative capacity [18]. 
Although the concept of social innovation and the role of the actors involved in it, such as civil social organizations or social entrepreneurs, are well hypothesized and developed in the academic literature. The importance of universities as agents of change has received less attention $[19,20]$.

The discussion on the way in which universities can contribute to social innovation has been developed under the concept of "the third mission of the university" that introduces a function presented as "a contribution to society" [21,22].

Universities dedicated to "third mission" activities are becoming engines that contribute to the social, economic, and cultural development of the regions in which they operate, transferring knowledge and technologies to industry and society in general [23-25]. However, the expression "third mission" is not clear [26]. Some authors have argued that the role of the third mission has to be interpreted in the sense of knowledge and technology transfer, in what has been called the "entrepreneurial university" [27]. In contrast, other authors refer to a broad set of activities carried out by universities that aim to promote entrepreneurial skills, innovation, social well-being and the formation of human capital $[28,29]$.

In any case, the third mission has introduced different forms of participation of universities in social problems through concepts and methodologies such as community participation, participatory research, service learning (and Science Shop), co-creation, citizen science, Living Labs, etc. and is committed to shaping the society of the future [19].

However, despite the widespread recognition of the role of universities in social innovation and even with the position of some authors who propose a fourth mission in which universities are asked to consider themselves "as open systems in relation to their environment and actively seek the participation of interest groups, including municipalities, industry, civil society or development agencies" [30], the real situation is that universities still lack of a clear strategy of social innovation [31].

Nowadays, universities face intense pressure to improve teaching and research quality, to internationalize and create excellence. This "mission overload" [32] has hampered the social innovation process, showing that there is still important work to be done.

In this context, this article attempts to shed light on how universities can contribute to the process of social innovation and thus to development and broad social change through the implementation of the service-learning course at the university. This purpose is achieved by analyzing and studying in detail the different stages of implementation, as well as analyzing and highlighting how an innovative social project can favor the development of SGD's through students. All of this implies an increase in social capital through the development of professionals, generating greater awareness and community involvement. Thus, the experiences, comments, reception of the course and involvement of our students in the development are collected.

The article is structured as follows. After the introductory section, we present the framework of the Comillas Pontifical University, highlighting its involvement with social commitment. We have used a method based on the study and stages of two success stories and on the questions and challenges we have faced in achieving them. The first of them is framed in the area of engineering for development and the second in the problem of the technological gap. For both, we highlight how they fulfill the key dimensions through which social innovation projects achieve their results. Finally, we present the conclusions and future lines of research.

\section{Pontifical Comillas University}

The Pontifical University of Comillas is a Jesuit university located in Madrid, whose origin dates back to 1908 with the creation of the School of Mechanics and Electricity (origin of the Catholic Institute of Arts and Industry (ICAI)). Although its founding objective was to provide technical training to factory workers, the high quality of its courses and its clear vocation for personal and human advancement made its programs recognized by the Spanish State and obtained civil validity in July 1957. Shortly later, in 1960, new additions 
were made to the ICAI university complex, adding new university degrees in Business Sciences, sometimes combined with the Law Degree (ICADE).

Currently, Pontificial Comillas University includes around 14,059 students, 1913 lecturers and researchers and 369 administrators spread over its three campus in Madrid. It is organized into five faculties (Faculty of Theology, Faculty of Canon Law, Faculty of Humanities and Social Science, Faculty of Economics and Business Administration and Faculty of Law), two schools (School of Engineering, School of Nursing and Physical Therapy) two inter-facultative Institutes (Institute of Family Studies and Institute of Studies of Migration), one International Doctoral School and two affiliated centers (CESAG and INEA).

Thus, Pontificial Comillas University is responsible for organizing the teaching for 24 bachelor's degree courses, 21 dual degree programs, 39 official master's degree courses, 40 comillas master's degree and 11 doctoral degree courses. In terms of internationalization, Comillas University has agreements with 656 international universities and receives an average of 2348 exchange students from around the world each year. Its values based on ethical principles, integrity, critical thinking, mutual respect, a vocation for service, compassion for the most vulnerable and sensitivity for sustainable development has also led him to develop other programs with high social impact such as learning and service, Social Business Consultancy or ICAI Social Lab among others.

Nowadays, Comillas Pontificial University has established itself as a prestigious international institution offering an innovative, experiential and global education for future leaders.

\subsection{Mission and Values of the University: Implementation of a Service and Learning Model for All Faculties}

In this context, and to make the university commitment to social innovation a reality, the service-learning methodology becomes an ideal channel for this [33].

On a theoretical level, Learning and Service is defined as "an educational proposal that combines learning and community service processes in a single well-articulated project where participants learn to work on real needs in the environment with the aim of improving it" [34]. The University has the challenge of defining and implementing a teaching methodology whereby students place their knowledge and skills acquired throughout their university studies (LEARNING) at the disposal of society (SERVICE) to solve specific problems, generally through social entities (PARTICIPATION) that work on different needs and causes whose ultimate aim is to improve the common good, while at the same time reflecting (REFLECTION) with critical thought on the process carried out.

It differs from and complements other actions and activities that can take place in the university environment also related to the SDGs, such as volunteering, curricular internships, challenge-based learning or specific activities in degree subjects.

Pontificial Comillas University has institutionally integrated service learning as a privileged tool to improve its teaching-learning strategies and to train future professionals who are conscious and socially committed. In the last five years, stable structures have been created to promote the voluntary participation of students in service-learning projects and an explicit commitment has been made to the implementation of the methodology in the curricular teaching. This commitment has also been made explicit and planned in various institutional documents. As a culmination of this commitment, in the 2018-2019 academic year, the ADE and Engineering degrees launched a Service-Learning course that, in a few years, has be taken by all undergraduate students at Comillas.

At the beginning of the 2013-2014 academic year, Comillas Pontifical University launched for the first time a structured offer of Service-Learning projects for volunteer participation. The program was born from the beginning with the involvement of the Faculty of Law and the creation of the ICADE Legal Clinic, and in successive years the ICADE Social Business Consultancy (Faculty of Business Administration) and Engineering + Social (currently ICAI Social Lab, School of Engineering) were born, to which is added the appointment of a person responsible for the promotion of service learning in the Faculty of Human and Social Sciences. After five years of implementation, the number of 500 students participating each year has been exceeded. The project has received the 
first prize in the XIV edition of the ABC Solidarity Award in the category of University Volunteering and one of the projects, "My grain of sand: constructing a safe migration", of socio-legal intervention in Melilla, was recognized as the best Service-lLearning project in the category of Social and Legal Sciences by the University of Valencia (II Edition Ragalo Awards, 2018).

In parallel, the university supports and encourages teacher training for the use of the learning service methodology as a pedagogical tool in the classroom. Around 50 teachers have received training and LS has been included in the teaching guide of several subjects. The project "Nuestra acción se multiplica-Proyecto Aprendizaje-Servicio entre Comillas y las escuelas rurales de Guatemala", in the subject of Didactics of Mathematics, received first prize in the category of Good Practices in University Social Commitment in the 5th edition of the Aristos Campus Mundus Awards.

Comillas Pontifical University, which institutionally supported from the beginning the implementation of the various service and learning (S\&L) proposals, explicitly incorporated its commitment to the model in its Strategic Plan 2014-2018 and in its renewed Educational Project (2016), which has as its explicit title "The best for the world: a shared learning".

The culmination of the university's institutional commitment is the creation of a compulsory subject for undergraduate students called "Service-Learning". Comillas does not renounce the development of the two previous models (voluntary participation in social intervention projects with S\&L methodology and S\&L in the classroom), which will continue to be promoted, but guarantees that $100 \%$ of its students will have at least one explicit and programmed experience throughout their academic training.

\subsection{A Model for Social Innovation Implemented in ICAI Engineering School}

Since the 2012-2013 academic year, taking advantage of the change of studies plan with the entry of the Bologna Plan, the Diploma in Personal and Professional Skills was created. It arose as a need to enhance the so called soft-skills among our students, as demanded by several of the most important companies in our country. To meet this demand, the school designed a 4-year curriculum (initially, although it has already undergone three modifications), which was able to train our engineers in these aspects.

The learning and service subject arose as a modification of the curriculum of the Personal and Professional Skills diploma, approved by the Governing Board in 2015.

The new diploma introduced a subject of 6 credits ( 60 working hours) in 4th year of industrial engineering (GITI), in telematic engineering (GITT) and in 2nd Master's degree, with the following descriptor:

"Learning and Service $4^{\circ}$ course ( 6 credits). Subject that integrates community service with the learning of competencies, skills and values."

From there, it was necessary to develop a subject that was able to extract the maximum potential of our students, already with a high knowledge in engineering, to apply it to social projects.

For this task, it was essential to be able to generate topics where the student 'would like to give the best of himself, and on the other hand was aware of the impact that social engineering can have on our lives, considering it as another way to develop their professional future.

\section{Designing a Learning and Service Subject for an Engineering School}

In this section we present the stages we have developed to implement the subject together with the service-learning methodology. To do this we have carried out the stages of designing the course, implementing the course based on six chosen areas, analysis of use cases and evaluation of the results through the feedback obtained and the results of the projects, which has led us to design some lines of action for future improvement.

To allow students for a better development of the projects according to their knowledge and areas of interest, six main areas of action were generated: 
- Education: workshops adapted from the ICAI Technological Campus, physics and mathematics support classes.

- Web design and development and apps: virtual stores, web page improvements.

- 3D printing and recycling: printing of chemotherapy boxes for children, printing of parts for children with severe disabilities, recycling of plastics and conversion into yarn for 3D printers.

- Collaboration with external foundations: projects requested from outside.

- Smart gardens: programming of sensors and installation to control and monitor the state of a plant, automatic irrigation ... etc.

- Engineering for development: cooperation projects for development in education, energy, recycling, resource optimization, etc.

These areas of action have been maintained during these three years since it is very easy for the student to select first the area of action and then the project associated with that area. In addition, depending on the area, we have developed specific training and workshops, so that students become socially aware and know the role of engineering in the area of interest, together with workshops and global conferences for all.

\subsection{Goals, Deriverables and Evaluation}

The main objective of the course, as stated in its technical data sheet is: " ... to complete the integral formation and values characteristic of our university, through a vocation of service and help to others. Specifically, the aim is that students know how to apply the knowledge and skills acquired throughout their studies to specific problems while offering a service to society, with special attention to vulnerable people and their circumstances, promoting the encounter with other realities". To do this, the student must develop a series of basic skills that are needed to take the course:

- Problem solving and decision making

- Organizational and planning skills

- Critical and self-critical skills

- Recognition and respect for diversity and multiculturalism.

- Ability to learn and work autonomously

- Action and quality orientation

As an outcome of the course, we set a set of learning results that all students were expected to have completed with varying degrees of success, that is: "Solve real challenges of Third Sector organizations (in a broad sense) in social engineering fields".

At this point, the development of competencies at a technical level related to the study career was completed in a satisfactory way in the projects, since the development of a real project encouraged creativity and project-oriented research. On the other hand, many of our students developed other types of not so direct and ponderable competencies such as empathy towards other social realities, familiarity with other environments, teamwork with interdisciplinary members and increased sensitivity towards more vulnerable groups as prove some of the comments received from the students:

"Even if at first I don't expect much from a subject after working on it I can discover that I like it and it provides a real service to society."

"This passion for knowledge came to me especially from my grandfather, the wisest and most humble man I have ever known. The way he listened so attentively to others no matter who they were or what they were talking about because he was fully aware that he was not in possession of the whole truth I have never seen in anyone else. It is these values that I want to develop throughout my career $[\ldots]$ ".

"Knowing that our work is going to be used, that it is not a simple evaluation of our competencies if not a work that thanks to our skills we have been able to carry out. That's why it's not enough just to get a pass, it's in our hands so that someone else tomorrow can spend less time assembling the mechanisms $[\ldots]$ ]" 
One of the biggest challenges we had at this point was the evaluation of our students, and the fact of being 'fair' when it comes to weighing their participation in the projects, their degree of involvement and their transformation process. In this sense, we were aware that not all the projects had the same degree of difficulty, some of them required moving to a certain area outside the university and others were developed in the school as a research project, so we developed a report with the basic points and elementary reflections that we wanted each of the students to consider during the course.

Thus, we focused the student's reflection on four basic points:

- On the service performed: social need addressed, causes and consequences.

- About the academic content: knowledge and associated skills that have been put into practice.

- About oneself: self-knowledge, emotions, values, feelings.

- About the civic commitment: sense of service and learning project in your undergraduate studies.

Thus, we present the students with a guide of orientated points to develop their learning memory around five pages:

1. Who I am?
a. Personal and academic background.

2. Service.
a. Environment.
b. Entity.
c. People.
d. Social problems.
e. Challenge posed.

3. The first days.

a. The beginning. How was the first encounter with reality.

b. First challenges that had to be faced.

4. The development of the project.

a. How have you been contributing ideas, knowledge .... to the challenge posed.

b. How did you work?

c. Remember any critical incident (doubts, difficulty) and how you solved it.

5. The practical workshops.
a. What I learned/what I didn't learn.

6. Farewell and final reflections.

a. Make a list of the five key ideas that you take away after completing the Service activity.

i. About the people you interacted with.

ii. About your learning.

iii. About the social issues you have worked on.

b. What idea did you have about the non-profit organizations and about the beneficiaries of this program when you started the course? Have your impressions about both changed, or have they remained the same now that the project has ended?

c. Service and learning in our School: what would you improve with respect to the activity you have done? Are there any activities that you think could be done as service learning that are not being done right now?

With this guide as part of the evaluation of the subject, we proposed the following percentages and points to be considered overall:

Work done (50\%)

Group and collaborative work (30\%)

- Interest shown in the subject. 
- Attendance to classes/working group meetings.

- Attendance to general training lectures of the subject.

- Attendance to specific training talks of the group.

- Obtaining information about the specific project.

- Dynamization and participation in the work group (distribution of tasks and times, leadership, group work ... ).

Presentation of the work to the rest of the students (in group and to the group).

Quality of the report (20\%)

Technical explanations.

Development of the report (analysis of the context, explanation, argumentation ... ).

Presentation (formal aspects, spelling and grammar).

Bibliography.

Considerations-personal reflections.

The student's evaluation process is completed with compulsory attendance at a number of master sessions that complement the activity carried out while offering testimonies, experiences and reflections from expert professionals on subjects such as social entrepreneurship, inequality, functional diversity, migration and care for our common home, among others.

At the end of each academic year, an activity report is drawn up which includes a summary of each of the projects carried out with the aim of informing the entire university community of the work carried out, highlighting the learning and service activity carried out by the students and, at the same time, explaining which Sustainable Development Goals have been involved in each project.

\subsection{Student's Comments and Learned Lessons}

The students' response to the subject has evolved considerably since it was introduced in the University's syllabus up to the present day. Thus, it has gone from being recognized as a compulsory subject that competed in time and dedication with the core engineering subjects to recognizing the University's DNA in it, involving them and their active and committed participation in the projects, knowing that, beyond the challenge of putting into practice their knowledge acquired during their university studies, they were working with, by and for people, for groups that required their time and skills to offer them a solution to the challenges and needs posed. We can distil from their comments and final evaluations the degree of personal satisfaction and the acquiring of competences that this has meant:

"Putting into practice all the knowledge acquired during the degree and deepening it is a very enriching challenge and if we add to this having the opportunity to study a new form of sustainable and low-cost energy generation, it becomes a very rewarding project".

- "We have always been used to studying to get good grades, focusing only on ourselves. However, this has been different from the point of view that we are offering something to someone and what we want to offer we want it to be the best and a job well done."

- "At ICAI I have had few volunteering experiences partly because of the pressure of studies. When I found out that we had this subject, I was very encouraged because of the idea of putting my engineering knowledge at the service of others."

- "The subject is very well thought out. However, I would have liked to have However, I would have liked to have been offered the activity from the beginning of the degree, not only in the last year. I feel that I would have learned more by communicating and getting closer to people than with short courses in Communication Techniques".

- "I am proud to say that this project has not been the work of one person, but has been the result of the work of 7 ICAI students. All the ideas and problems have been solved together and with the help of others, no one has been alone."

- "I have learned that behind a simple project like a box in which waste is thrown to get compost, it can be much more complex than that and involves making transcendental decisions." 
"It has been thanks to this subject that I have really realized how fortunate we are and that with a little effort you can help people to the point of wanting to continue doing projects of this style in my future as an engineer."

"Discovering a completely different way of living than I am used to reflecting on what lifestyle is better and how to be able to learn from a completely different way of living."

"I have also realized how important it is to have motivation when doing any project. And this is a project to do with motivation and affection thinking of others."

"I have learned to be more self-critical and make objective assessments of the work being done. I have realized that it is very important to detect when things are being done well and when they are being done badly so that I can redirect the tasks and meet the objectives."

Among the main lessons learned from the Service-Learning project, in addition to the relevance and effectiveness of developing all the phases of the project cycle (preparation, implementation and evaluation) in a staggered and successive manner and at each entity's own pace, we highlight the following:

The success of the activity is marked by the degree of appropriation of the project by the student. The training components that can be applied are important in the initial stages, but appropriation is key and involves getting to know the organizations and the people who benefit from them. This dynamic process of being informed, feeling challenged and becoming involved is the key to a full commitment and involvement with the organization and its cause.

The project developed requires a personalized accompaniment of the students, shared between the social entity and the University. In this scope, communication between the actors involved, the student, social entity and university, must be constant and fluid.

The result and impact of the project is greater if the work is done as a team, in groups of students and not individually. In this aspect, we have count with several professors of the School who wanted to participate voluntarily and external assessors such as Cindy Mason, who participated in several projects as technology advisor.

Challenges, objectives and results must be predefined, so that the project does not become too big and does not meet the expectations of either the social entity or the student. It is essential to make the work carried out visible both to the beneficiary organization and to the University.

In some specific circumstances, some of the learning and service projects have been the basis for the completion of Final Degree Projects (TFG) or Master's Degree Projects (TFM).

\section{Practical Approaches of Social Engineering}

To date, the course has been developed during three academic years, 18-19, 20-21, and 21-22, with a total of 152 students the first year, 180 the second and 354 in the last edition. The number of projects is around 120 in total for some 40 NGOs with which we have maintained good relations for the most part. In general, the degree of satisfaction of the students has been high and has exceeded their expectations, since they initially thought that it was going to be a personal burden, and in many cases, it has made them evolve in the social and personal sphere. In fact, several of these students (approximately 10 per year) have continued with their projects and have even taken the lead in proposing new projects for their classmates. From the total of projects, we have selected two quite innovative ones in which the level of cooperation and involvement of the students was very high.

\subsection{Sustainable Projects}

Performing everyday tasks in developing countries is made difficult mainly due to a lack of resources. The scarcity of technology is a reality, on the other hand, resources such as wood, plastic caps or soda cans are relatively easy to obtain anywhere in the world. For this reason, we are launching a series of projects based on the recycling and reuse of plastics and all kinds of disposable items for their subsequent reuse.

During the 2020-2021 academic year, we proposed a challenge to build under extreme conditions a solar oven that could provide a solution to the melting of plastics (as seen 
in Figure 2), especially for areas with a low level of development such as a concentration camp, and that allowed the subsequent creation of simple parts, thus contributing to their reuse as part of sustainable development.

Specifically, it consisted of the design and manufacture of a solar oven from recycled materials capable of reaching more than 125 degrees Celsius in a solar exposure period of $6 \mathrm{~h}$. Temperature measurements were recorded through an Arduino board programmed using MATLAB Simulink. The development was led by Cristina Puente Rueda, a 4th grade student of industrial technologies (mechanical specialty), with the supervision of professors Maria Ana Sáenz and Juan Luis Zamora.

Thus, the project has three distinct parts: design and construction of the prototype, development of the temperature measurement program and analysis of the results obtained. The criteria followed for the design of the prototype follow two lines: the first is that the materials must be recycled and accessible in disadvantaged areas, and the second is that they must be capable of providing the ideal environment for collecting the sun's rays and achieving adequate heat retention. The materials used to build the oven are: two wooden crates, cardboard, snack bags, a refrigerator glass, black paint and joining elements: nails, duct tape and white glue, as seen in Figure 1.

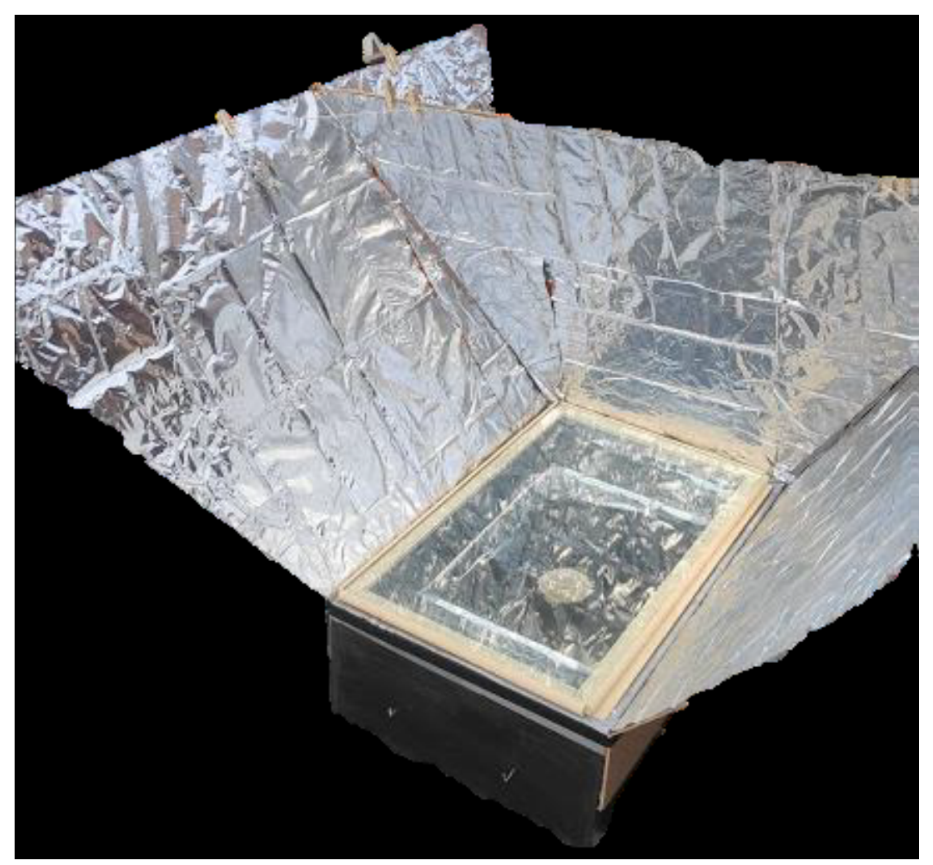

Figure 1. Prototype of solar oven built with recycled materials.

The total cost of the components to build the oven was just over 17 euros, which makes it more than affordable for developing countries.

In order to accurately measure the temperature, an arduino sensor was used to capture the heat balance in all parts of the furnace and the maximum levels reached. In this way, measurements were made of the temporal evolution of the internal temperature in the oven for seven days. The temperature graphs all follow the same pattern: first a very steep rise in temperature lasting less than an hour, then a period of stability sometimes disturbed by cloudy intervals, and finally a gentle drop in temperature until approaching a horizontal asymptote coinciding with the ambient temperature, as seen in Figure 2.

As final results, and to implement the project in a real environment, the project provided three aspects to be taken into account:

- Using recycled materials and an imperfect insulation system, high temperatures can be reached, the maximum temperature recorded being $126.25^{\circ} \mathrm{C}$. Although recycled 
materials are not ideal because the dimensions and shape of the available elements vary, a good result can be achieved.

$\bigcirc \quad$ The radiation that causes the main heating in the oven is direct radiation, diffuse radiation plays an almost negligible role. During cloudy intervals, when there is no direct radiation reaching the oven, there is a steep drop in temperature. On days when there is no cloud cover, the temperature increase occurs at a constant gradient and is then maintained over a long period of time.

Other parameters such as humidity or wind have their own effect on the warming of the oven. Humidity is not decisive for the oven heating. Relative humidity data was initially collected because it seemed that the percentage of relative humidity was directly proportional to cloudiness, but it has been demonstrated that this is not the case. The wind makes it difficult for the reflectors to focus the sun's rays on the interior of the oven, causing the oven to heat up slower.

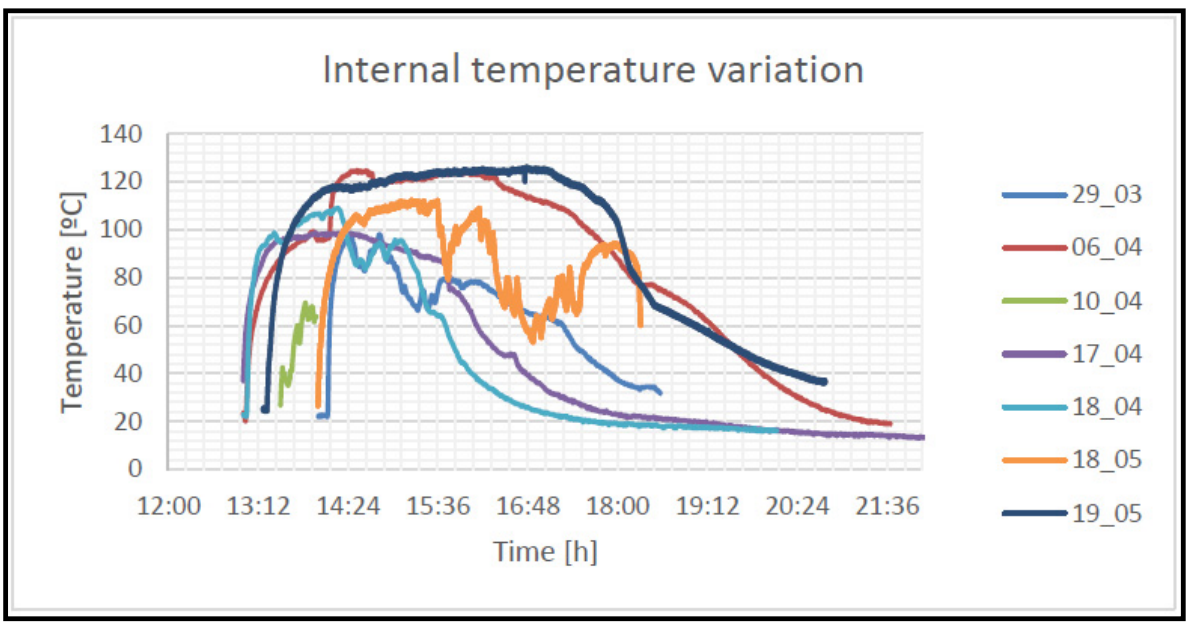

Figure 2. Internal temperature variation.

To evaluate this project, we have used the model proposed by Benneworth and, Cunha 2015 [14], which allows us to control the dimensions to be developed so that a project can have a social impact (see Table 1):

Table 1. Dimensions proposed by Benneworth and Cunha [14] for the Case Study 1.

\section{Outcomes of a Socially Innovative Practice}

Developing novel solutions

Creating social value promoting community development

Forming wider collaborative networks

Challenging existing social institutions through this collaborative action
Design, Construction and Characterization of a Handmade Solar Oven for Social Purposes

This project is original and has been designed and constructed by the student and her directors using recycled materials without any external help or reference.

This project meets SGD 7, 13 and 10, as it proposes a new way of transforming energy, in a clean way, preserving the environment and thus contributing to reduce inequalities among communities.

This solar oven is intended to serve in refugees camps or communities with low resources, so to create collaborative networks with these kinds of resources.

The implementation of a solar oven could serve for multiple actions, from cooking to melt bottle plastic to create prothesis, so could challenge social institutions to promote these types of actions. 


\subsection{Economic Projects for NGO's}

In addition to the social impact produced by collaboration between students and social organizations, in certain Learning-Service projects the economic component is indirectly incorporated, as the student's technical contribution provides added value at no cost to the organization that could not otherwise be satisfied due to the scarcity of economic resources available for all the challenges or improvements possible in an organization.

As a sample of projects with these favorable economic effects for organizations, we present a national project in Spain that has involved the presence of students specializing in telecommunications engineering.

The Kyrios Personal Support Foundation is a general interest social action organization that develops social projects that support the socialization of people with borderline intelligence and offers support to social entities that work for the rights of people with functional diversity. One line of work is Kyrios Artes Gráficas, the special employment center of the Kyrios Foundation.

The project developed by the students of the ICA School consisted of improving and developing the website of the printing company Kyrios Artes Gráficas (https: / / www. ftkyrios.org/index.php/cee-inicio, accessed on 25 November 2021) see Figure 3. As a special employment center, it carries out a productive activity of design and graphic printing, competitive and of quality, giving a job opportunity to people with disabilities, offering them the necessary labor and social support to develop their work and motivate them towards the ordinary market. There are currently five people with intellectual disabilities on the staff who actively participate in all the work of the print shop, supervised by professionals from the Kyrios Foundation who support them in their day-to-day work.

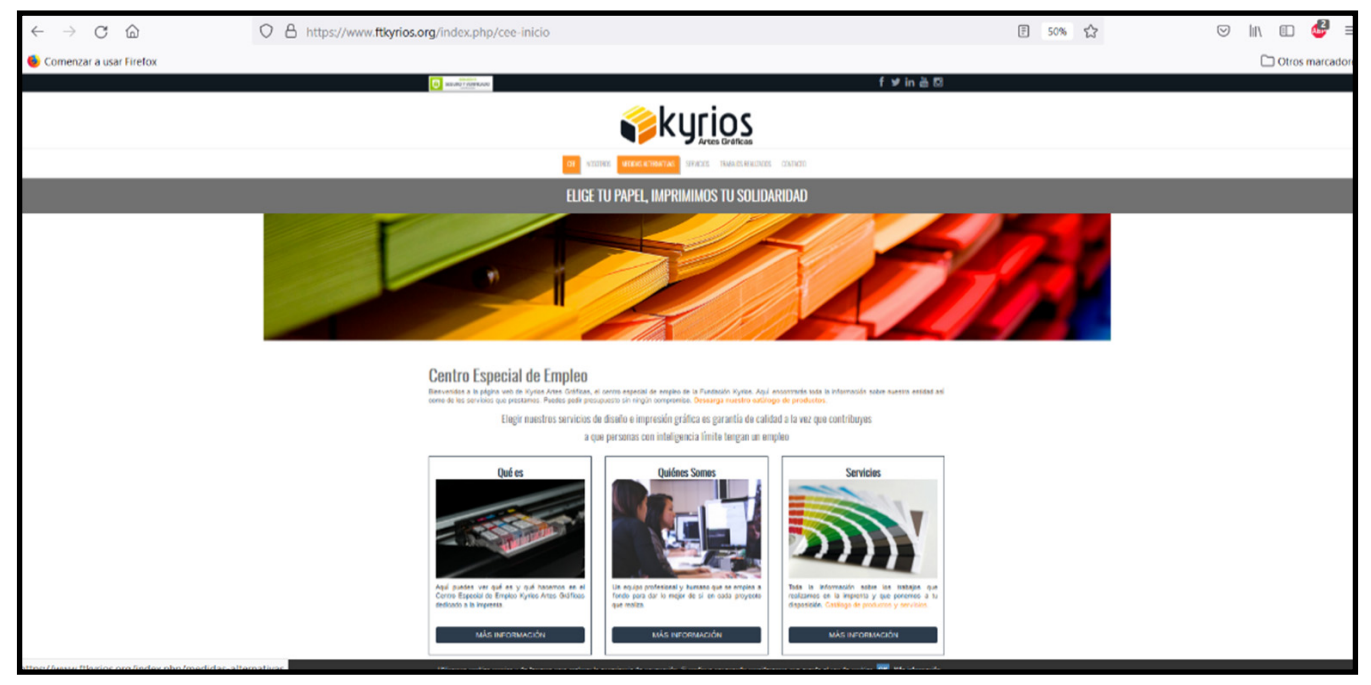

Figure 3. Kyrios website.

The objectives of the collaboration project consisted of improving the existing functionalities of the website, adding new ones and working on SEO to position the website on the internet, providing it with greater visibility and therefore greater possibilities of generating work requests that result in greater income for the printing company.

As we did in the previous case, we are going to evaluate this project through the dimensions proposed by Benneworth and Cunha (2015) (see Table 2). 
Table 2. Dimensions proposed by Benneworth and Cunha [14] for the Case Study 2.

\begin{tabular}{ll}
\hline Outcomes of a Socially Innovative Practice & Kyrios E-Commerce Website \\
\hline Developing novel solutions & $\begin{array}{l}\text { This project is original and has been developed } \\
\text { from cero, taking as basis tutorials from how to } \\
\text { create e-commerce sites. Is the first e-commerce } \\
\text { site for this NGO. }\end{array}$ \\
\hline $\begin{array}{l}\text { This project aligns with the achievement of the } \\
\text { SDGs and specifically connects with the } \\
\text { development }\end{array}$ & $\begin{array}{l}\text { following: Decent work and economic growth } \\
\text { (SDG 8). Industry, Innovation and } \\
\text { Infrastructure (SDG 9), increasing access to } \\
\text { information and communication technology. }\end{array}$ \\
$\begin{array}{l}\text { Reducing inequalities (SDG 10). } \\
\text { Forming wider collaborative networks }\end{array}$ & $\begin{array}{l}\text { This site will serve to broadcast easily their } \\
\text { products so will form collaborative networks } \\
\text { derived from it, as happens with many site on } \\
\text { the internet. }\end{array}$ \\
\hline $\begin{array}{l}\text { Challenging existing social institutions through } \\
\text { this collaborative action }\end{array}$ & $\begin{array}{l}\text { With this site, we pretend to increase the sales } \\
\text { volume, being a more valuable NGO able to } \\
\text { serve more disabled people. }\end{array}$ \\
\hline
\end{tabular}

\section{Conclusions and Future Works}

The University has evolved in an agile and dynamic way over the last ten years to assume its shared responsibility to train people who are capable of leading a professional life committed to sustainable development and based on values.

Comillas Pontifical University embraces this responsibility and in its Strategic Plan 2019-2023 states that its vision is "to form responsible, trustworthy and upright people; aware, competent, critical, compassionate and committed; to form discerning subjects with the capacity to choose, having memory of the good received and projected to the greatest service becomes more important than ever. In this sense, the acquisition of cognitive competences is important, but above all the development of non-cognitive and transversal skills, and the continuous dynamic of active learning throughout life".

In the development of these professional skills and abilities, the University has opted for the subject of Learning and Service, which has played a leading role, as it concentrates in its process many competences that are not exclusively academic, such as the resolution of specific problems, innovation, teamwork, empathy and relations with third parties, communication and commitment to solidarity.

As a result, among the group of students who have taken the course, an increase in social competencies has been obtained, developing skills of empathy, communication and problem solving linked to a greater awareness at the social level, which has led, in their own words, to a better relationship with their community in terms of solidarity and awareness (all this is extracted from the observation of their learning processes). In fact, $10 \%$ more students continue to work in social projects or in contact with social entities as a result of the Learning-Service course.

As weak points to be improved, it should be pointed out that the learning process is not homogeneous in all projects. As there are six areas of development, there are projects such as those presented in this work that are highly evolved, and others that have not been successful in their achievement. The fundamental causes observed in this regard have been twofold: (i) either the students did not approach the project with sufficient responsibility and time, (ii) the social entity did not have a clear will for the project to go ahead, and there was no person responsible for giving feedback on issues such as implementation or steps to follow.

Another factor to consider in many projects is space. In certain projects such as those of integral ecology they have had to work for two years in a classroom of about two square 
meters and with little light to test the 'intelligent' agriculture devices, until finally, the university has given a space in one of its campuses to build a greenhouse and a garden where to develop the projects (https: / / www.comillas.edu/noticias/20-comillas-cihs / 1604 -comillas-pone-en-marcha-un-huerto-ecologico, accessed on 25 November 2021).

As future work, we have no data on the economic and social impact that this initiative may have. This is one of the aspects that slows down investment by universities in social innovation projects and on which we are currently working.

Author Contributions: Conceptualization, C.P., M.E.F. and R.V.; methodology, M.E.F., C.P. and M.A.S.-N.; software, C.P.-R. and C.M.; validation, C.P.-R., M.A.S.-N. and C.M.; investigation, M.E.F., R.V. and C.P.; resources, M.E.F. and C.P.; writing-original draft preparation, M.E.F., R.V., C.P. and C.P.-R.; writing-review and editing, C.M.; funding acquisition, C.P. and M.E.F. All authors have read and agreed to the published version of the manuscript.

Funding: This research received no external funding.

Institutional Review Board Statement: The study was conducted according to the guidelines of the Declaration of Helsinki, and approved by the Institutional Review Board of ICAI School of Engineering in Comillas Pontifical University, date of approval 9 December 2021.

Informed Consent Statement: Informed consent was obtained from all subjects involved in the study.

Data Availability Statement: No data reported.

Conflicts of Interest: The authors declare no conflict of interest.

\section{References}

1. Raghu, G.; Karnoe, P. Path Dependence and Creation; Psychology Press: Hove, UK, 2013.

2. Mieg, H.A.; Töpfer, K. Institutional and Social Innovation for Sustainable Urban Development; Routledge: Milton Park, UK, 2013.

3. Ackoff, R.L. Ackoff's Best-His Classic Writings on Management; John Wiley: New York, NY, USA, 1999.

4. Benneworth, P.; Cunha, J. Universities' contributions to social innovation: Reflections in theory \& practice. Eur. J. Innov. Manag. 2015, 18, 508-527.

5. Avelino, F.; Wittmayer, J.M.; Pel, B.; Weaver, P.; Dumitru, A.; Haxeltine, A.; Kemp, R.; Jørgensen, M.S.; Bauler, T.; Ruijsink, S.; et al. Transformative social innovation and (dis)empowerment. Technol. Forecast. Soc. Chang. 2019, 145, 195-206. [CrossRef]

6. Mulgan, G. Social Innovation: What It Is, Why It Matters and How It Can Be Accelerated; Working Paper 2007; Skoll Centre for Social Entreprenuership: Oxford, UK, 2007.

7. Castro-Arce, K.; Vanclay, F. Transformative social innovation for sustainable rural development: An analytical framework to assist community-based initiatives. J. Rural Stud. 2019, 74, 45-54. [CrossRef]

8. Moulaert, F.; Mehmood, A.; MacCallum, D.; Leubolt, B. Social Innovation as a Trigger for Transformations: The Role of Research; European Commission, DG for Research and Innovation: Brussel, Belgium, 2017; 108p.

9. Mulgan, G. The Process of Social Innovation. Innov. Technol. Gov. Glob. 2006, 1, 145-162. [CrossRef]

10. Mulgan, G. Social Innovation Theories: Can Theory Catch Up with Practice? Challenge Social Innovation: Potentials for Business; Social Entrepreneurship, Welfare and Civil Society; Springer: Berlin/Heidelberg, Germany, 2013; pp. 19-42.

11. Edwards-Schachter, M.; Wallace, M. Shaken, but not stirred: Sixty years of defining social innovation. Technol. Forecast. Soc. Chang. 2017, 119, 64-79. [CrossRef]

12. Westley, F.; Antadze, N.; Riddell, D.J.; Robinson, K.; Geobey, S. Five configurations for scaling up social innovation: Case exemples of nonprofit organizations from Canada. J. Appl. Behav. Sci. 2014, 50, 234-260. [CrossRef]

13. Cajaiba-Santana, G. Social innovation: Moving the field forward. A conceptual framework. Technol. Forecast. Soc. Chang. 2014, 82, 42-51. [CrossRef]

14. Benneworth, P.; Cunha, J.; Oliveira, P. Handbook of Research on Global Competitive Advantage through Innovation and Entrepreneurship; IGI Global: Hershey, PA, USA, 2015; pp. 1-24.

15. Antadze, N.; Westley, F.R. Impact Metrics for Social Innovation: Barriers or Bridges to Radical Change? J. Soc. Entrep. 2012, 3, 133-150. [CrossRef]

16. Antadze, N.; Westley, F.R. Funding Social Innovation: How Do We Know What to Grow? Philanthropist 2010, 23, 343-356.

17. Mcgowan, K.; Westley, F.R. At the Root of Change: The History of Social Innovation; Palgrave Macmillan: London, UK, 2015.

18. Avelino, F.; Wittmayer, J. Shifting Power Relations in Sustainability Transitions: A Multi-actor Perspective. J. Environ. Policy Plan. 2015, 18, 628-649. [CrossRef]

19. Morawska-Jancelewicz, J. The Role of Universities in Social Innovation within Quadruple/Quintuple Helix Model: Practical Implications from Polish Experience. J. Knowl. Econ. 2021. [CrossRef]

20. Bayuno, B.B.; Chaminade, C.; Göransson, B. Unpacking the role of universities in the emergence, development and impact of social innovations-A systematic review of the literature. Technol. Forecast. Soc. Chang. 2020, 155, 120030. [CrossRef] 
21. Abreu, M.M.; Demirel, P.; Grinevich, V.; Karataş-Özkan, M. Entrepreneurial practices in research-intensive and teaching-led universities. Small Bus. Econ. 2016, 47, 695-717. [CrossRef]

22. Urdari, C.; Farcas, T.V.; Tiron-Tudor, A. Assessing the legitimacy of HEIs' contributions to society: The perspective of international rankings. Sustain. Account. Manag. Policy J. 2017, 8, 191-215. [CrossRef]

23. De Jong, S.; Barker, K.; Cox, D.; Sveinsdottir, T.; Van Den Besselaar, P. Understanding societal impact through productive interactions: ICT research as a case. Res. Eval. 2014, 23, 89-102. [CrossRef]

24. Secundo, G.; De Beer, C.; Schutte, C.S.L.; Passiante, G. Mobilising intellectual capital to improve European universities' competitiveness. Technol. Transf. Off. Role J. Intell. Cap. 2017, 18, 607-624. [CrossRef]

25. Agasisti, T.; Barra, C.; Zotti, R. Research, knowledge transfer, and innovation: The effect of Italian universities' efficiency on local economic development 2006-2012. J. Reg. Sci. 2019, 59, 819-849. [CrossRef]

26. Pinheiro, R.; Langa, P.V.; Pausits, A. One and two equals three? The third mission of higher education institutions. Eur. J. High. Educ. 2015, 5, 233-249. [CrossRef]

27. Trencher, G.; Yarime, M.; McCormick, K.B.; Doll, C.N.H.; Kraines, S.B. Beyond the third mission: Exploring the emerging university function of co-creation for sustainability. Sci. Public Policy 2014, 41, 151-179. [CrossRef]

28. Etzkowitz, H.; Ranga, M.; Benner, M.; Guaranys, L.; Maculan, A.M.; Kneller, R. Pathways to the entrepreneurial university: Towards a global convergence. Sci. Public Policy 2008, 35, 681-695. [CrossRef]

29. Di Berardino, D.; Corsi, C. A quality evaluation approach to disclosing third mission activities and intellectual capital in Italian universities. J. Intell. Cap. 2018, 9, 178-201. [CrossRef]

30. Domenico, D.; Verena, B. The role(s) of universities in dealing with global wicked problems through multi-stakeholder initiatives. J. Clean. Prod. 2014, 106, 68-78.

31. Cinar, R.; Benneworth, P. Why do universities have little systemic impact with social innovation? An institutional logics perspective. Growth Chang. 2020, 52, 751-769. [CrossRef]

32. Enders, J.; de Boer, H. The mission impossible of the European University: Institutional confusion and institutional diversity 2009. In European Integration and the Governance of Higher Education and Research; Amaral, A., Neave, G., Musselin, C., Maassen, P., Eds.; Springer: Dordrecht, The Netherlands, 2009.

33. Miñano, R.; García, M. Dossier REDS: Implementando la Agenda 2030 en la Universidad. Casos Inspiradores de Educación para los ODS en las Universidades Españolas; Red Española para el Desarrollo Sostenible (REDS/SDSN-Spain): Madrid, Spain, 2019; pp. 6-7.

34. Cedena, B. Conoces el Aprendizaje-Servicio? Guía Básica para Organizaciones; Plataforma del Voluntariado de España: Madrid, Spain, 2020; pp. 16-17. 